\title{
A CROSS SECTIONAL STUDY OF NUTRIENT INTAKE AMONGST RURAL ADOLESCENT GIRLS OF KATIHAR
}

\author{
Shahid Iqbal' ${ }^{1}$ Rashid Ahmad Khan ${ }^{2}$ \\ ${ }^{1}$ Assistant Professor, Department of Community Medicine, Katihar Medical College, Katihar. \\ ${ }^{2}$ Assistant Professor, Department of Community Medicine, Katihar Medical College, Katihar.
}

\section{ABSTRACT}

\section{OBJECTIVE}

A cross sectional study of the nutrient intake of rural adolescent girls was carried out in four villages of the Department of Community Medicine, Katihar Medical College, Katihar.

\section{MATERIALS AND METHODS}

A household survey was carried out in the villages. A list of all the adolescent girls in the age group of 10-19 years was prepared by enumeration through house to house visit. All adolescent girls were included in the study. A predesigned and pretested questionnaire was used to collect data on socio-demographic variables and anthropometric variables. A 24-hour recall method was used to assess nutrient intake. Data generated was entered and analysed using epi info 2000. Nutrient intake was compared with ICMR Recommended Dietary Allowances (RDA). Nutritional status was assessed by BMI for age.

\section{OBSERVATIONS}

The mean height of the adolescent girls was $142.9 \mathrm{~cm}$. Overall, $57 \%$ of the adolescents were thin (BMI full age $<5$ th percentile far CDC 2000 reference) and $43 \%$ of the adolescents were normal (BMI for age between $5^{\text {th }}-85^{\text {th }}$ percentile for CDC 2000 reference). The average energy intake which was $1239.6 \pm 176.4 \mathrm{Kcal} /$ day was deficient of RDA by $39.1 \%$. The average protein intake was $39.5 \pm 7$ $\mathrm{gm} /$ day. It was deficient by $36.1 \%$ and the average iron intake, which was $13.2 \pm 2.5 \mathrm{mg} /$ day was deficient by $48.2 \%$.

\section{CONCLUSION}

The findings reiterate the dietary deficiency among adolescent girls, which adversely affects the nutritional status. If the poor nutritional status is not corrected promptly before they become pregnant, it adversely affects the reproductive outcome. If we have to meet out the goals of reproductive and child health programme intervention strategies to improve the dietary intake of adolescent girls are needed so that their requirements of energy, protein, vitamins and minerals are met.

\section{KEYWORDS}

BMI, Calorie, Dietary Recall, Iron, Protein.

HOW TO CITE THIS ARTICLE: Iqbal S, Khan RA. A cross sectional study of nutrient intake amongst rural adolescent girls of Katihar. J Evolution Med Dent Sci 2016;5(4):253-255, DOI: 10.14260/jemds/2016/53

\section{INTRODUCTION}

There are nearly one billion adolescents in the world accounting for $20-25 \%$ of the total population in the developing countries. This particular group of population is likely to increase rapidly in the next 30 years due to population momentum effect.(1) owing to sudden and special growth taking place in this phase, the nutritional requirements also increase tremendously compared to preceding years of growth. During this phase, diet should provide not only sufficient calories, but also essential elements and nutrients such as protein, vitamins and minerals required for growth.

Nutrition is an input to the foundation of health and development. Better nutrition is a prime entry point to ending poverty and a milestone to achieving better quality of life.

Financial or Other, Competing Interest: None.

Submission 11-10-2015, Peer Review 12-10-2015,

Acceptance 07-01-2016, Published 13-01-2016.

Corresponding Author:

Dr. Shahid Iqbal,

Assistant Professor,

Department of Community Medicine,

Katihar Medical College,

Katihar.

E-mail: shahidiqbalkmc@gmail.com

DOI:10.14260/jemds/2016/53
Freedom from malnutrition is a basic human right and their alleviation is a fundamental prerequisite for human and national development.

Malnutrition is associated with significant morbidity, mortality and economic costs in developing countries.(2) It also affects the reproductive outcome of the mother. Interventions which targeted pregnant mothers failed to improve the reproductive outcomes and there is an urgent need to improve the nutritional status before a woman becomes pregnant.(2) To design appropriate strategy to tackle the poor nutrition among adolescent girls and eventual morbidity and mortality, it is essential to study the dietary pattern. Hence, the present study was under to know the nutrient intake among adolescent girls of rural Katihar.

\section{MATERIAL AND METHODS}

A cross sectional study was carried out in the four adopted villages such as Hajipur, Chapada, Bompada, Field Tola during January 2014 to June 2014 of the Department of Community Medicine, Katihar Medical College Katihar.

A household survey was carried in all the four villages to enumerate unmarried adolescent girls in the age group of 1019 years. All the adolescent girls were included in the study. A predesigned and pre-tested questionnaire was used to collect data on socio-demographic and anthropometric variables. 
A 24-hour recall method was used to assess nutrient intake. The nutrient intake was calculated using tables of nutritive value of Indian foods.(3) Data generated were entered and analysed using epi info 2000 . The CDC 2000 reference was used to assess the nutritional status.(2) The Chi-square test was used for testing statistical significance. The level of significance was taken at $\mathrm{P}$ Value $<0.05$.

\section{OBSERVATION}

Adolescent unmarried 430 girls enumerated, participated in the study. In present study $57 \%$ of the adolescent girls were thin and $43 \%$ were normal. None of them were overweight or obese. The prevalence of thinness was significantly higher $67.6 \%$ in early adolescence than in late adolescence $55.4 \%$.

The adolescent girls (82.5\%) had calorie intake less than $1400 \mathrm{Kcal} ; 7.5 \%$ girls had calorie intake less than $1000 \mathrm{Kcal}$. The average energy intake was $12.39 \pm 176.4 \mathrm{Kcal} /$ day. The calorie intake of adolescent girls was less than the Recommended Dietary Allowance (RDA) for their age. The average calories intake was deficient by $39.1 \%$. The average protein intake was $39.5 \pm 7 \mathrm{mg} /$ day, which was deficient by $36.1 \%$. The average iron intake was $13.2 \pm 2.5 \mathrm{mg} /$ day and was deficient by $48 \%$ [Table].

\begin{tabular}{|c|c|c|c|c|c|c|c|c|c|c|c|c|}
\hline \multicolumn{13}{|c|}{ Table Nutrient Intake of Adolescent Girls } \\
\hline \multicolumn{13}{|c|}{$\begin{array}{l}\text { NUMBER NUTRITIONAL CALORIE (KCAL/DAY) PROTEINS IRON } \\
\text { Status * BMI for Age }\end{array}$} \\
\hline \multicolumn{2}{|c|}{$\begin{array}{c}\text { AGE } \\
\text { (Years) }\end{array}$} & $<5^{\mathrm{TH}}$ & $\begin{array}{l}5^{\mathrm{TH}}- \\
85^{\mathrm{TH}}\end{array}$ & $\mathbf{R D}^{* *}$ & $\begin{array}{l}\text { MEAN INTAKE } \\
\text { ISD }\end{array}$ & $\begin{array}{c}\% \\
\text { DEFICIT } \\
* * *\end{array}$ & $\begin{array}{c}\text { RD } \\
\mathbf{A}\end{array}$ & $\begin{array}{l}\text { MEAN } \\
\text { INTAKE } \\
\text { ISD }\end{array}$ & $\begin{array}{c}\% \\
\text { DEFICIT }\end{array}$ & RDA & $\begin{array}{c}\text { MEAN } \\
\text { INTAKE } \\
\text { ISD }\end{array}$ & $\begin{array}{c}\% \\
\text { DEFICIT }\end{array}$ \\
\hline 10 & 35 & 25 (71.4) & $10(71.4)$ & 1970 & $1130.08 \pm 13.0$ & 42.6 & 57 & $35.8 \pm 6.1$ & 37.2 & 19 & $11.52 \pm 2.1$ & 39.3 \\
\hline 11 & 40 & $30(75.0)$ & $10(25.0)$ & 1970 & $1177.1 \pm 1989$ & 40.2 & 57 & $38.5 \pm 7.3$ & 32.4 & 19 & $12.85 \pm 2.7$ & 32.3 \\
\hline 12 & 50 & $34(68.0)$ & $16(32.0)$ & 1970 & $1208 \pm 163.3$ & 38.7 & 57 & $39.2 \pm 6.6$ & 31.3 & 19 & $12.96 \pm 2.4$ & 31.7 \\
\hline 13 & 52 & $34(65.4)$ & $18(34.6)$ & 2060 & $1224.1 \pm 149.6$ & 40.5 & 65 & $38.1 \pm 5.4$ & 41.3 & 28 & $12.81 \pm 1.9$ & 54.2 \\
\hline 14 & 40 & $24(60.0)$ & $16(40.0)$ & 2060 & $1244.5 \pm 173.6$ & 39.6 & 65 & $38.8 \pm 6.9$ & 40.1 & 28 & $13.39 \pm 2.3$ & 52.1 \\
\hline 15 & 50 & $24(48.0)$ & $26(52.0)$ & 2060 & $1282.1 \pm 169.2$ & 37.8 & 65 & $40.9 \pm 7.0$ & 36.9 & 28 & $13.90 \pm 2.5$ & 55.3 \\
\hline 16 & 47 & 23 (48.9) & $24(51.1)$ & 2060 & $1243.6 \pm 159.5$ & 39.6 & 63 & $39.4 \pm 5.9$ & 37.4 & 30 & $13.24 \pm 2.2$ & 55.8 \\
\hline 17 & 49 & $23(46.9)$ & $26(53.1)$ & 2060 & $1322.6 \pm 183.4$ & 35.8 & 63 & $42.3 \pm 7.8$ & 32.8 & 30 & $13.98 \pm 2.7$ & 53.4 \\
\hline 18 & 34 & $17(50.0)$ & $17(50.0)$ & 2060 & $1260.8 \pm 1954$ & 38.0 & 63 & $40.4 \pm 8.4$ & 35.8 & 30 & $13.68 \pm 2.6$ & 54.4 \\
\hline 19 & 33 & $11(33.3)$ & $22(66.7)$ & 2060 & $1284.1 \pm 179.4$ & 37.6 & 63 & $40.6 \pm 7.2$ & 35.5 & 30 & $13.97 \pm 2.4$ & 53.4 \\
\hline $\begin{array}{l}\mathbf{T} \\
\mathbf{O} \\
\mathbf{T} \\
\mathbf{A} \\
\mathbf{L}\end{array}$ & 430 & $\begin{array}{c}245 \\
(57.0)\end{array}$ & $\begin{array}{c}185 \\
(43.0)\end{array}$ & - & $1239.6 \pm 176.4$ & 39.1 & - & $39.5 \pm 7.0$ & 36.1 & - & $13.2 \pm 2.5$ & 48.2 \\
\hline & & & 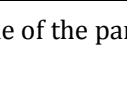 & & Dercente & . & & intake & Die & & & \\
\hline
\end{tabular}

\section{DISCUSSION}

During adolescence poor nutritional status is an important determinant of health outcomes. Short stature in adolescents resulting from chronic under nutrition is associated with reduces lean body mass and deficiencies in muscular strength and working capacity. In the present study, $57 \%$ of the adolescents were thin while $43 \%$ were normal.

The high prevalence of thinness is reported from the developing world. National Nutrition Monitoring Bureau.(4) also showed that the height, weight and growth rates of adolescents of low income groups were about $70-80 \%$ of those of well to do adolescents. Choudhari et al.(5) reported that $68.52 \%$ of the adolescents had BMI less than 18.5 in rural area of Varanasi. In the present study, thinness was significantly higher in early adolescence $(67.64 \%)$ than in late adolescence (55.42\%), Deshmukh et al.(6) reported that majority (53.8\%) of the adolescents were thin, only $2.2 \%$ were overweight while $44.0 \%$ were normal. Medhi et al.(7) reported that $41.3 \%$ of the adolescent girls were thin.

In the present study, the average energy intake was $1239.6 \pm 176.4 \mathrm{Kcal} /$ day and the calorie intake was deficient by $39 \%$ Chaturvedi et al.(8) reported that the calorie intake was deficient by $36 \%, 34 \%$ and $26 \%$ in the age group $10-12$ years, 13-15 years and 16-18 years respectively. Yadav and Singh. ${ }^{(9)}$ reported that the calorie deficiency among adolescents was $29 \%$.
The average protein intake was $39.5 \pm 7 \mathrm{mg} /$ day and the protein intake was deficient by $36 \%$, Chaturvedi et al.(8) reported that in the age group 10-12 years, 13-15 years and 16-18 years, the protein deficit was $29 \%, 32 \%$ and $23 \%$ respectively. Yadav and Singh. ${ }^{(9)}$ reported that the magnitude of stunting was $60 \%$ among the adolescents.

The average iron intake was $13.2 \pm 2.5 \mathrm{mg} /$ day and was deficient by $48.2 \%$. Butley. ${ }^{(10)}$ found that the mean iron intake was $7 \pm 3.1 \mathrm{mg}$ in the age group of $14-16$ years in low socioeconomic status, while in upper socio-economic status it was $18.5 \pm 5.2 \mathrm{mg}$. She also observed that in the age group of $17-18$ years, the mean iron intake was $10.1 \pm 3$.1mg in lower socioeconomic status and in upper socio-economic status it was 24.13.7mg. Earlier diet surveys in adolescent population have also shown that the diets are inadequate in all nutrients including iron, proteins, calcium and calories.(11-13) Similar findings were also reported by Reddy.(14) and Vasanthi et al.(15)

\section{CONCLUSION}

The findings reiterate the dietary deficiency among adolescent girls which adversely affects the nutritional status. If the poor nutritional status is not corrected promptly before they become pregnant, it will adversely affect the reproductive outcome. If we have to meet out the goals of reproductive and Child Health Program, intervention strategies to improve the dietary intake of adolescent girls are needed so that their 
requirements of energy, protein, vitamins and minerals are met.

\section{REFERENCES}

1. United Nations fund for population activity. The South Asia conference on adolescents. UNFPA, Kathmandu: 1998.

2. Physical status: The use and interpretation of anthropometry technical report series Geneva: World Health Organisation: 1995, Report No. 854.

3. Indian council of medical research nutrient requirements and recommended dietary allowances for Indian Hyderabad National Institute of Nutrition Indian Council of Medical Research 2000, P.43-9.

4. National nutrition monitoring bureau, diet and nutritional status of rural population, NNMB Technical Report No. 21: National Institute of Nutrition. Indian Council of Medical Research Hyderabad: 2001.

5. Chaudhari P, Vir S. Prevention and strategies for control of iron deficiency anaemia $1^{\text {st }}$ ed. Nutrition in children: Developing country concerns. In Sachdeva HP Choudhary P editors. New Delhi: Cambridge ness 1994 P. 492-524.

6. Deshmukh PR, Gupta SS, Bharambe MS, Dongre AR, Maliye C, Kaur S, et al. Nutritional status of adolescents in rural Wardha, Indian J. Pediater 2006;73:139-41.

7. Medhi GK, Hazarika NC, Mahanta J. Nutritional status of adolescents among tea garden workers. Indian J Pedatier 2007;74(3):43-7.
8. Chaturvedi S, Kapil U, Ananasekaran N, Sachdev HP, Pandey RM, Bhanti T. Nutrient intake amongstadolescent girls belonging to poor socio-economic group of rural area of Rajasthan Indian Pediatr 1996; 33:197-20.

9. Yadav R, Singh P. Nutritional status and dietary intake in tribal children of Bihar Indian Pediatr 1999; 36:37-42.

10. Chakraborty N. Health and nutritional status of adolescent girls in a selected slum of Bombay. Dissertation, Bombay SNDT University 1992, P: 98.

11. Pushpamma P, Geervani P, Devi NL. Food intake nutrient adequacy and anthropometry of adolescent in Andhra Pradesh, Indian J Med Res 1982; 75:61-7.

12. Thimmayamma BV, Rau P, Rao KV. Socio-economic status, diet and nutrient adequacies of different population groups in urban and rural Hyderabad, Indian J Nutr Dietel- 1982; 19:173-83.

13. Kapil U, Manocha S, Bhasin S. Dietary intake amongst"Well to do" adolescent boys and girls in Delhi Indian Pediatr 1993;30:1017-9.

14. Reddy V, Rao PN, Satry G, et al. Nutrient trends in India. Hyderabad: National Institute of Nutrition. Indian Council of Medical Research 1993, P-33.

15. Vasanthi G, Pawanshe AB, Susie H, et al. Iron nutritional status of adolescent girls from rural area and urban slum, Indian Pediatr 1994; 31:127-32. 